\title{
WORLD RELIGIONS AND THE NEW AFRICAN UNION - A CRITICAL INTERROGATION... \\ OR: A PROLEGOMENON TO AN ECONOMICS OF RELIGION
}

\author{
Department of Theology and Religious Studies \\ University of Botswana
}

\begin{abstract}
In this essay I attempt to examine the place of the world religions (that is religion qua religion) in the context of the ongoing effort toward African Renaissance and Development. This kind of analysis becomes imperative in the light of the efforts of African Religions" Leaders to be relevant to contemporary African visions for development, revival and survival in the global environment, as is witnessed in the recent visit of these leaders to the President of South Africa, Mr Thabo Mbeki, who is also the current Chairman of the new African Union (the proposed replacement for the Organization of Africa Unity) in October, 2002, asking to be consulted on matters of concern to Africa and to be involved in the development process. In the light of the above, numerous questions come to mind: (a) Given the history of the world religions (especially Christianity and Islam) in Africa and the world, can religion now be a partner for progress, development, unity and peace? (b) To what extent has the posturing of unity among diverse religions and their leadership been reflected in the declamations of the leaders in their different domains, especially in their canvassing for followership and supremacy in socio-political and economic domains for adherence and supremacy over the minds and pockets of their followers? Put differently, do these leaders now teach the sanctity of all religions and equality of all the paths to the Supreme Being? (c) Whose interest are the leaders canvassing on the international African forum? And, (d) In the face of secularism and democratic waves sweeping the world, can undemocratic institutions be instruments for democratic and egalitarian development?
\end{abstract}

Key Words: African Renaissance, Leadership, World Religions

\section{Introduction}

It is not emotion, feeling, or the "heart" (metaphor), or simply the senses (sensory organs tuning to the world as such) that leads to religion. Nor is it the juvenile, the primitive or the delirious tremens in the infantile ego that seeks after the supernatural. It is reason - the astute mind, a tormented but unsatisfied consciousness, a challenged intellect, an unencumbered thought or the afflicted and bemused rational self - that leads to religion. Religion is like any of the other cultural artifacts that humans have devised to deal with reality, to cope with the world and to survive in the universe, by creating assurances and managing apparent chaos that seeks to annihilate or compromise human existence. It is the recognition of the epistemic inadequacy, of the cognitive insufficiency, and of the gap between what humans desire to know and what is known, that have compelled historic and contemporary humans to seek after the supernatural, the whole other, the source being or the light without or within, the revelatory transcendent, as a way of illuminating the unknown and probably 
making known the "unknowable." Other intellectual and practical means of dealing with reality that humans of all epochs and ages have evolved are art, science and technology, history, poetry, music, politics, economics, etc. These are significant in the sense in which they facilitate the understanding and resolution of certain aspects of the dilemma of existence. But our concern here is with religion, and hence, our focus will be on religion; especially how religion helps the human to master reality.

There are three main categories of persons involved in the various religions, once the visions have encrusted and congealed into some fixed doctrine. These are the missionaries, the theologians and the rank and file believers. In some instances the first and second are merged, determining the institutional structures that bear and perpetuate the religion. While the last category are often humble enough to admit the limitations of their understanding of the tenets, visions and numens of the religion; they are the bedrock of religious faith and, in some instance, fundamentalism and fanaticism, funding and feuding over religion, on the one hand, while on the other they are more tolerant of divergences of beliefs from their accepted ones.

When we talk of the visit of the religious leaders to President Thabo Mbeki in this essay, it is mostly the missionaries, the parsons, the clergy, the priests, the mullahs, the bearers of the proselytizing torch that we have in mind. They are the recognized heads of the religious institutions in the various local and national communities. These are people often trained to lead the religious organizations, and to canvass for new votaries and to make converts. These are the persons who claim to know the mind of the divine in the various religions, knowing as it were, the absolute, eternal, everlasting truth to which there are no alternatives, and the acknowledgement of any dilution would create an endangerment of the faith as accepted and as transmitted, threatening chaos to the terrestrial and extraterrestrial planes. In most instances these are not intellectuals who examine, analyze, critique and in.vestigate the foundations of the faith. They are usually teachers (preachers, priests or leaders) of the religion in the sense of being the mouthpiece of the religion; the ones who are supposed to be the repositories of the ideas enshrined in the faith and who are sought after to provide illumination on the tenets of the faith. These are people with vested interest in the survival of the faith, and in the continued growth in the numbers of the devotees of the faith. But I need to attenuate what I have said here with a caution, because, there is the danger of the ideas expressed to be unnecessarily universalized to even the religions that do not have rigid compensatory clergy-ship. In such religions which recognize the individual nature of the religious faith and practice, without compelling membership to attendance of sessions, meetings, mass, worship or liturgy, clearly there will be variations in the kind of interest that the leadership we are discussing here will have in the survival and perpetuation of the religion. But after that is said, we still have the residue of the devotees who make the existence of the faith a source of their own sustenance and existence.

This first category of persons in religion are separate or separable from the theologians, mostly academics or academically inclined persons interested in the religion's belief system, and who study various aspects of the religion - history, sociology, philosophy, psychology, ethics, etc. The theologians are often more liberal, in the sense of being more tolerant of the existence of other faiths and the "probability" that other faiths may also attain a truth similar to that found in their own faith. Often if they have proclivities toward exclusionism and fanaticism they are able to cloak these in a façade of liberalism and pretended tolerance. There are instances where there is a coalescence of the parson and the theologian, breeding persons highly knowledgeable in the religion and tolerant of other religions, because of the fact that they are more receptive to the fundamental truth, which they are ready 
to concede to other religions on a level footing with their own faith. But there are instances where it is this category of hybrid persons who are the apologetics of their faiths, leading the paths of dogmatism and intolerance, because they are trusted as scholars to be leaders of thought, champions of truth, and the enlightened few who are more likely right than wrong and so trusted to encompass more knowledge than the ordinary clergy. But we can easily separate the first from the second category of persons. And it is usually the second category of persons mostly who are present in conferences like this, even though the admixture is also more than liberally represented. We will have time to examine why the attitudes are mixed later, but for now it may be important to observe that the participants in the first World's Parliament of Religions were mainly the second group or admixture of the first and second - and it was largely an American meeting. But in staying away from the Parliament, along with other leaders like the Sultan of Turkey, the position of the Archbishop of Canterbury speaks eloquently to the distinction we are making in this introduction. He says:

( $\mathrm{t}$ )he Christian religion is the one religion. I do not understand how that religion can be regarded as a member of a Parliament of Religions without assuming the equality of the other intended members and the parity of the positions and claims (Eastman, 1999:6, italics and bold emphasis mine).

One could contrast this with the very apposite analogy of the frog in a well used by the legendary Hinduist, Mahatma Gandhi. He says:

We must not, like the frog in the well, who imagines that the universe ends with the wall surrounding his well, think that our religion alone represents the whole Truth and all the others are false (Eastman, 1999:69, italics and bold emphasis mine).

I believe it is impossible to estimate the merits of the various religions of the world, and moreover I believe that it is unnecessary and even harmful even to attempt it. But each one of them, in my judgment, embodies a common motivating force; the desire to uplift man's life and give it purpose (p. 71, italics mine).

Probably he was able to say this because he was a cross between a theologian and an "ordinary" follower of a faith. But applying the title theologian to him will be making it seem as if he made the study of religions a source of income and a means of livelihood, and paradoxically, it would be disingenuous to suggest he was an ordinary follower of Hinduism also, because his devotion to the study of religions and the knowledge of diverse religious experiences far surpasses what ordinary folk ever attain in their religious experiences or in their reflections on those experiences vis-à-vis their ability to acknowledge the existence of other religions as a derivative of their received instruction within their own faiths, given the limitations of the exigencies of survival.

By and large, the third category of persons consists of the followers of religious ideas. Not the determiners of the content of faith, they rely on the leadership of the parsons, clergy and leaders of faith for guidance and instruction. In most cases they seldom question the disquisitions of the parsons, nor would they suspect the motives of the theologians, as they are often too preoccupied with the daily needs for survival to have the leisure to reflect on the veridicality and veracity of religious dogma. It is this category of persons that often is manipulated and used for all kinds of ends they can hardly understand or explain in many of the separatist and destructively divisive antagonisms of the many generations of religious interaction of different faiths.

Our concern in this essay is with understanding the place of religion from the perspectives of the first two groups of people involved in religion, hoping that we may be able to see beyond the historical, social, psychological or even scientific study of religion to the 
often ignored aspect of economics of religion. Our point of departure in this essay is that it is reason, aware of the necessity for survival of the self in the light of various forces stacked against this survival that seeks the support of supra-natural powers to achieve the survival. Thus, our major thesis is that it is economics, the sensible and the rational calculation of risk, and the desire to have the best means to achieve the desired goals of sustenance and survival that leads to religion. It is expected that by placing on the front burner the economic agenda behind all religions we may dissipate some of the mysticism and mythology that suffuses religious discourse. I am thus suggesting, in essence, that there is need for a new intellectual discipline called Economics of Religion, to help us to unravel the potent implications of the economic foundations of religions, which often generates, or degenerates into, the religious wars that humanity has had and continues to have even in the 21st century. By so doing, we may see the relationship between the new African Union and the African and other world religions in a different light, thereby facilitating a better evaluation and understanding of the call for relevance of religion by religious leaders, or even be able to see whether the call was misplaced. In any case, we are well aware of the relationship between politics and religion - religion has often claimed to be not just a matter of spiritual conviction but a way of life, a way of social, political and moral existence. And the incestuous relationship between religion and politics is the best testimony that we can provide for this kindred affinity, leading to various contestations and ideological conflicts. It is the missing link in this analysis that is being formally called for in this discussion, so that we bring it to clear focus, rather than pretend it is not important or that it is not the overriding moderating factor in many, if not all, religious disputations that humanity has endured from the world religions.

\section{Religion}

Let me say up-front that I do not wish my discussion to be taken for what it is not. I am not providing a study in history of religions in Africa or in the world. That would involve me in a task for which I am least qualified, as I cannot be representing the origins, periods and movements of various religions in Africa or in the world without becoming an impostor in that hackneyed discipline called history of religions; but I can make allusions to events in contemporary African societies to enunciate my point regarding the place of religion in contemporary Africa and, by extrapolation, the future Africa we may "desire" to have. This is also not an exercise in comparative religions in Africa; a task for which a student of philosophy simpliciter, like myself, can lay no claim to expertise. Furthermore, this is not a discussion in sociology or psychology of religion; for such a discussion would have to entail clear disciplinary competence which I cannot lay any pretense to having. Having provided these caveats to protect me from vilifications from those who may query the motive(s) for my discussion, it is necessary that I say that, as a student of philosophy, with a stake in Africa (including the African Diaspora, being the dispersed branches of the African tree of humanity, which has waited patiently and still waits patiently for Africa to get it right) and its well-being, I cannot but be concerned, to the point of eliciting critical issues which demand careful reflection, in order to see how answers to them facilitate the imperative of African renaissance.

There is a temptation to traverse already well-beaten ground on the question of definition and genesis of religion and religious systems (that is, what are the essential forces, factors, and mental dispositions that give rise to religion) and religious institutions in human societies as means of prefactory ingress into the discussion of religions, but this temptation will be resisted, as it would not add much to the understanding and appreciation of the is- 
sues to be discussed in this essay. Persons interested in this kind of prefactory excursion may do well to read JN Amanze's (2002) African Traditional Religions and Culture in Botswana, in which the author provides a very careful and competent review of the literature on definitional issues and theories of the origins of religions in human societies. But it is important to indicate, for our purpose, that the discussion will take as given certain features, attributes or fundamentals of religions and religious systems and institutions. It is the givenness of these commonalities that would make it possible at every turn, when we mention religion in contemporary intellectual discourse, not to have to specially mention which religion or which religious origin is intended. Clearly, some religions may have more features or religion demarcating features than others; this would not be ground for supposing one religion superior to another or contrariwise, one religion inferior to another, as no religion can claim exclusive privilege of truth - given the fact that truth itself is a complex phenomenon that all humans seek in various ways and under various guises and to various degrees of success and according to demands and needs. We may also say that it is possible that other scholars may actually be able to point out the inexhaustiveness of the categories or features highlighted below; this should not vitiate the discussion, as our intention is to indicate features just to facilitate the discussion, not to claim perfection!

Having said that, we may suggest the following as some of the main features of most, if not all, religions:

1. Deity, Supreme Being, An Absolute, A universal Ideal, Supernatural Beings, Spiritual Essence

2. A Founder, "Myth" of Origin, Genesis, Source and Stories about Ultimate Reality and Terminus Ad Quiem or End of the Universe

3. Scripture, Text, Codex, Dogma, Doctrine, Disclosure, Revelation, Body of Truth, and Theology

4. Worship, Rituals, Liturgy, Communion, Prayer and Curses - Raison d'être

5. Priesthood, Leadership, Custodians of Faith

6. Sacred Places, Sites, Spaces

7. Morality and Ethics, Definitions of Right and Wrong

8 Symbols, Artifacts, Emblems, Art

9. Believers, Worshippers, Devotees, or the Faithful, and Humanity writ large

10. Religions and Welfare - the economic dimension of religion and humans.

Depending on the diverse ecological circumstances, intellectual experiences and existential exigencies of the humans who originate a religion, and depending on the ends to which the religion redounds, the features highlighted above may be all represented or partially represented in the repertoire of religious expression and the experiences they prescribe. We may note, however, that the application of the terminology of "religion" to all the experiences, dispositions and beliefs to which we have referred is not without problems, as many peoples of the world would not accept the term religion as used in the Western perspective to describe their belief system and the associated practices. This is especially so of Eastern societies of India, China and Japan on the one hand, and African societies on the other.

Thus, what is clear from the above is that human beings of all epochs, since the dawn of consciousness, have had to address fundamental questions such as: How shall I live? What is the good life? Does life have meaning? Is there anything beyond life? Why is there something rather than nothing? Is there an origin for what there is? Does everything have meaning? What, beyond myself, has influence in my life and that of my immediate environment? 
What makes things work? Is there order in the Universe? What is responsible for that order? What should I do to gain the favours and avoid the disfavours of the(se) power(s)? How much of what I have is mine or belongs to my society or to the(se) power(s) identified? How much control do I have on what happens in the world and around me? Am I just a pawn in the games of forces beyond my control? Are the forces capable of being used against other forces - human, natural, supernatural - that may affront me at every turn? The questions are endless, and our search for answers leads us in diverse ways, one of which is religion. According to Douglas Davies (1994):

The human animal is characterized by its large brain, possessing an ability for rational and symbolic thought. This tremendous capacity to engage with the environment seems to be the expression of one of the drives of human nature. The urge to understand and comprehend the world and the universe as our species" environment results not only in science but also in religion. Though science and religion may deal with different aspects of life they are both attempts at explaining the world around us (Holm, 1994:6).

I would go further as I have done to include other areas of intellectual searches mentioned earlier. This will have the advantage of putting on par intellectual efforts that are on the same level, regardless of the latter day successes of the sciences by comparison with the disappointments with the hopes associated with religious opinions. And it is clear that the diversity of human experience creates a diversity of religions, and many of us utilize more than one religious perspective in dealing with the perplexities of life within a single work-aday experience - navigating the conundrums of Christianity, Islam, African religion, science, technology, ideologies and secularism in one single breath without any fear of contradiction or ennui.

It may be said that the basic fact of human search for survival has been the grasping for whatever straw will bridge the chasm of uncertainty, which the absence of sure knowledge impels on humans at every turn. It is no less remarkable that the human mind has alighted on art, science and technology than that it has alighted on religion. For the unavoidable insight that generates the bright lights of art, science, technology also leads to religion even more so in the case of religion, giving to each according to their capacity to comprehend. If this be so, then there is clear justification in the declaration of Vivenkananda that:

It is the same light coming through different colours... But in the heart of everything the same "I am in every religion as the thread through a string of pearls. And wherever thou seest extraordinary holiness and extraordinary power raising and purifying humanity, know ye that I am there" (quoted in Eastman, 1999:7).

This idea was echoed by John Henry Barrow as follows:

(i)t was felt by many that to claim everything for Christianity and deny any good in other religions is not Christian, and is an impeachment of that Divine goodness which is not confined to geographical limits and which sends its favours upon the just and upon the unjust.. Christians come to rejoice with an increased hopefulness as they perceived that religion, however imperfect, is, after all, the best there is in man, and that God is not confined in his mercy and benefactions to any favored race or people...

So many roads lead up to God

T'were strange if any soul should miss them all (Eastman, 1999:9).

In very subtle ways, humans have been led into the same kinds of conclusions which were reached by those of many millennia before our contemporary time. We are very conversant of the famous California and Australia fires, which ravage hectares of land to no end, destroying everything in its path as it devours all living and non-living organisms. But in one of those fires in suburban California about five years ago, in a neighbourhood that used to 
be a serene community of upper-middle class residents numbering some hundreds, a woman's house was "miraculously" spared when everything else was destroyed all around. She came home from an out of state trip where she had learnt on the news of the fires in her neighbourhood to find her property the only one spared and declared that it was her God that did the miracle. For miracle it was, that only her property was spared the scourge of the fire. Why would she think it was God who spared her property - could it be she was special to God or had a new mission for which that was a sign? Were the neighbours whose properties were destroyed any less godly than she was? Could there be scientific explanation for the fact that her house was spared - like wind direction, absence of fuels to carry the fire to her doorstep, sudden rainfall, timely intervention of firemen, etc.? Why would her consideration have ended so terminally at the postulation of miracle?

Whether it is looking into the Tesbiu of the Moslem, the Rosary of the Christian, the Ifa of Orunmila, the Satellite pictures of the Meteorologist, or the biopsy of the Pathologist, we as humans must continue to search for explanations. Those who have attained the pinnacles of scientific intellectualism are aware that after all is said and done, even to the chagrin of those with a proclivity to scientistic ideologism, we all find that we know little and that what is in need of knowing far outstrips what we know. This comes with the recursiveness of the call to humility on the part of the most knowledgeable among humans - though the halfwit (persons of little knowledge and half-baked ideas) are the most pontifical amongst us, claiming to have certainties where the wise are wary of opening their mouths lest they misspeak.

Since it is the age of holography and cyber information, we may take a few examples to illustrate our point here. Consider some of the spectacular events in the period of rule of the current President of America (USA):

(a) Shortly after he took office there was the event of 9:11. This killed so many Americans and non-Americans that even the President had to go into hiding, not staying in one place for more than a few hours, and only returning from hibernation when it was apparent that the "Armageddon" or day of judgment for America was over.

(b) Take the case of the crash of Columbia shuttle flight on re-entry of Earth's space, a major catastrophe in American NASA efforts, killing peoples of many nationalities, including the first Jew in space. The last time a similar crash in the NASA history of a shuttle flight was during the Presidency of the father of the incumbent.

(c) Within a week there was the news of Eastern snowstorms in America which killed more than two dozen people on President's Day. In many instances the snowstorms were unprecedented in living memory.

(d) In Chicago a nightclub stampede killed more than two dozen people.

(e) Rhode Island nightclub killed at least 96 revellers (CNN, 23.02.2003).

(f) On March 25, 1990 at Happy Land Social Club New York City 87 were killed in fire (during Papa Bush's Presidency).

Apart from these there have been other disasters involving planes, trains or other natural phenomena. In other parts of the world there were the Bali nightclub bombing, the South Korea subway fire, floods killing lots of people in Europe and South Asia. For one, it could have been seen in the USA some hundred years ago as the sign that God or some other supernatural power was not favourably disposed to the rigged Bush Presidency. While in the events in other parts of the world, it could have been argued that their support for the Bush administration is what has been bringing damnation to these regions. While all kinds of other explanations would be possible, ranging from human error to greed and probability 
calculus, given the odds and so on, clearly the idea mentioned above concerning seeking supernaturalistic explanations would not be ruled out. In fact, even in America there are those who are already making allusions to such explanations, even suggesting that what we are witnessing is child's play compared to the conflagration that the stiff-necked and ungodly regime will visit on the world!

One may wonder what all these have to do with religion. But the link is not difficult to see once we begin to recognize that explanatory models help us to understand, control and manage our universe, such that when we are not able to understand we are not willing to give up and accept our ignorance. As a consequence, the same wonder that leads to philosophy, science and art leads to religion. In fact, I remember quite clearly the seventies when the Ibadan floods were very serious, before the canalization of the River Ogunpa. At that time people were always asking that prayers be held in churches and sacrifices made in the shrines to deal with the demon of the river or to control the demon. Clearly people were not unmindful of the numerous contributory factors that led to the loss of life and property, in the form of blocking of the path of the river with buildings, similar to the ozone layer depletion caused by the greenhouse effect especially generated by America which consumes more than half of all the energies produced on earth and the attendant flooding, fires, earthquakes, El Nino and tsunamis that follow. Just as people are not unmindful of how indiscriminate sex, drug abuse, sexual perversions and medical accidents cause HIV/AIDS, yet we hear various moralistic and religious explanations - including the almost assinine governmental hypocrisy in the Republic of South Africa that there is no link between HIV and AIDS.

In a world with a munificence of idiosyncrasies and eccentricities, it is not out of reach to see that what the religious patriarchs are enjoining us to embrace in their attempt to be relevant is to play on our current fears, fears of the discredited leadership that continues to pauperize Africa, in order to entrench their divisive agendas. Clearly, one can see that religion is (should I say, has) not the unifying mantra that the leaders have sought to make of it. The jostling of the leaders of the religions for (TV) camera attention that took place at the press conference after the meeting with the President of South Africa that we are referring to is clear evidence of the subterranean motivation behind the new-found unity of purpose and front of relevance that the leaders were attempting to sell to the political directorates of Africa and the gullible populace that are unwise to the tricks of institutional religion.

The relevance of what we have considered so far is simple. Given the characteristics that we have indicated with reference to religion, it is clear that religion serves and will continue to serve humanity in various sways. However, whether the service rendered by religions will continue to be at once dubious and positive will depend largely on the maturity of religious leaders in being magnanimous enough to separate their own self-interest from the corporate interest of their communities. For example, one could excuse the mendacity of the early church leaders in Africa as a consequence of ignorance when they denied the existence of religion in traditional African societies, or when they labeled African religious ideas and doctrines as idolatry and paganism, and when Muslim leaders of yesteryears regard peoples of other faiths as Kafirs and outcasts. Such generosity will be wasted and irresponsible in the 21 st century if contemporary scholars of religion and theologians still preach in their schools of thought, in their churches and in their mosques the backward and renegade ideas of peoples of other faiths as idolaters and pagans, especially now that we are fortunate enough to know that there are no societies that do not have ideas relating to religion demarcating characteristics highlighted, which we repeat here for emphasis: 
Deity, Supreme Being, An Absolute, A Universal Ideal, Supernatural Beings, Spiritual Essence; a Founder, "Myth" of Origin, Genesis, Source and Stories about Ultimate Reality and Terminus ad quiem or End of the Universe; a Scripture, Text, Codex, Dogma, Doctrine, Disclosure, Revelation, Body of Truth, and Theology; a Worship structure, Rituals, Liturgy, Communion, Prayer and Curses - Raison d'être; a Priesthood, Leadership, Custodians of Faith; some Sacred Places, Sites, Spaces; an Ethic, Morality and Ethics, Definitions of Right and Wrong; some Symbols, Artifacts, Emblems, Art; the Believers, Worshippers, Devotees or the Faithful, and Humanity writ large; and an economics of Religion utility and Welfarecentrism - that is, the economic dimension of the relationship between religion and humans.

According to the Dalai Lama:

Religion should never become a source of conflict, a further factor of division within the human community. For my own part, I have even, on the basis of my deep respect for the contribution that other faiths can (sic) make towards human happiness, participated in the ceremonies of other religions. And, following the examples of a great many Tibetan lamas both ancient and modern, I continue to take teachings from as many different traditions as possible. For while it is true that some schools of thought felt it desirable for a practitioner to stay within his or her own tradition, people have always been free to do as they think fit. Furthermore, Tibetan society has always been highly tolerant of other peoples" beliefs. Not only was there a flourishing Muslim community in Tibet, but also there were a number of Christian missions which were admitted without hindrance. I am therefore firmly in favour of a liberal approach. Sectarianism is poison (Eastman, 1999:128, italics mine).

This view was reinforced by Chinua Achebe (1989) in Hopes and Impediments when he recounted how Christianity came to his village Ogidi in the eastern part of Nigeria during his childhood. According to him, his uncle allowed the mission to start in his compound, and allowed members of his family to attend their meetings, while he continued with his traditional Igbo beliefs, but had to ask the mission to leave his compound on account of the elegiac and somber nature of the songs of the new mission which resembled funeral rituals unbefitting to the vibrancy that should emanate from the homestead of a prominent Igbo family! In his inimitable way, Achebe says:

Apparently the first missionaries who came to my village went to Udo Osinyi to pay their respects and seek support for their work. For a short while he allowed them to operate from his compound. He probably thought it was some kind of circus whose strange presence added lustre to his household. But after a few days he sent them packing again. Not, as you might think, on account of the crazy theology they had begun to propound but on the much more serious grounds of musical aesthetics. Said the old man: "Your singing is too sad to come from a man's house. My neighbours might think it was my funeral dirge" (Achebe 1989:32, italics mine for emphasis).

Achebe's father joined the new faith and there was no difficulty between both men on account of differences of faith. One could replicate the same experience in many African societies, in how Christianity and Islam were received by peoples who were originally devotees of various African religions.

You may notice that I have not for once used the phrase "African traditional religions", because it is one of the misnomers making the rounds in contemporary African humanistic scholarship, as if the other religions that have come to challenge African religions were not the "traditional religions" of the strangers who brought them! I recollect my own childhood also, whereby though of very devout Christian parentage, I had an uncle who was a traditional chief of the town and who was both Christian and the priest of our ancestral religion. Every year we looked forward to the festival of Elefson, as it was a season of celebration, 
while we equally enjoyed the Christmas. In fact, in my town, when it was Christian festivity, everyone in town participated, equally when it was Muslim festivity and indigenous religious festivity.

This brings us to the point where we must acknowledge the strangeness of the fact that no religious wars were fought in Africa before the arrival of the sibling traditions developed in the Arabian Desert. This is a challenge that missionaries, theologians and followers of the imported Desert religions need to ponder seriously, especially given the factors of inebriating physical and mental debilitation and stupefying inertia which these religions have generated on the African continent. Thus, we ask, why is there so much religious schism in Africa today? Why are brothers at sisters" throats and vice versa on behalf of God? Why do we forget that we may all be attempting to find the same salvation, even though our paths to the salvation may differ? Does it not make sense that the same Supreme Being may reveal to different peoples in different ways? Can we not simply leave the Supreme Being alone to resolve whatever linguistic and cultural differences we may have attached to the revelations we may have received without arrogating to ourselves divine wisdom?

While in the next section we will attempt to provide answers to the questions raised above and those questions we posed at the beginning of this essay, I will be very happy if the reader/audience would look inward and try to suggest to him/herself what may be responsible for the so-called divisiveness of religion. Could we imagine how much pain has been caused by what should be an anecdote to suffering and sorrow? We will proceed to discuss some of the features of religion, in order to show that the economic factor is of critical importance in religion, even though this has been pushed to the background now, in order to show a disinterested side of religion, while the interest being pushed now is mainly that of the parson.

\section{Religion and Human Needs; Souls, Stomachs, Supreme Beings!}

Let me declare my hand straight away, regardless of the risk of irking many people and possibly making a few enemies! I do not believe that the primary reason for religion, whether it be institutional or it be personal religion, is about the souls of humans or about human spirit, or even about our human interest in what matters to the Supreme Being and to other supernatural agencies or the interest of these supernatural beings. I believe that religion is primarily, fundamentally and intrinsically all about the human stomach, human welfare and especially the sustenance of self (self-interest) and welfare of the leadership of organized religions. In other words, the leadership of the world religions - Christianity and Islam in Africa - could not care less about the souls of their followers, as this is very secondary to the perpetuation of the institution called missionary; nor could they care a whit about what the Supreme Being thinks about their activities or the welfare of their followers in so far as their entrenched parasitic positions are not threatened by any smart Alec! These "wild" assertions will be justified in due course. For now, let us pursue a milder strand of our position, if only as a diversion away from the virulent and probably offensive implications of what has been declared here.

In every human society efforts are made to cater to the welfare of members. Making provision for needs has been, and continues to be, the central concern of humans since the dawn of civilization and awareness. This also comes with the tacit understanding of certain criteria of measuring success and successful provision for the needs of self, members of one's family, one's group, one's community and society at large, and the attendant recognition of the various disruptive and facilitating forces out there which make such efforts suc- 
cessful or botched. Thus, apart from merely seeking explanations for the varied phenomena that humans experience, imagine or conceive, there is the pressing need to find means of easing the burden of existence placed on humans in the world of scarcity and hardship.

The basic instrument or ingredient of human survival has been the land. The land, in all societies, has played a dominant role in the understanding of life, existence, survival, growth, success, provision for now and for the future, leisure and pleasure, poverty and wealth, art and culture, etc. Because of this, primordial attachments to land have been inescapable, and separation from land has been seen, in virtually all societies, as the beginning of destruction of identity, of survival and of civilization and cultural survival. Humans in every epoch have done everything to adapt to the land on which they find themselves, and have taken measure to replenish, even create, the land as much as is feasible, transferring the land from generation to generation of ownership. In many instances it is the individual that owns land in more egocentric, individualistic and atomistic societies, while in other more communal and integrated societies it is the family or the community, the society and their representatives who own the land in trust for members of the family, community or society.

Take the case of our understanding of the Supreme Being. Confronted with the enormity of the universe, the response is one of finding a survival kit. Doing so implies seeking for sustenance, but the vagaries of the environment in which humans live bedevil the exercise with so much uncertainty, leading as Rudolf Otto (1950) has posited the recognition of a multi-variety of beings numinous, numinous others which are shrouded in haze and even infatuation - mysterium tremendum et fascinans (Otto, 1950:52). He says:

That which the primitive religious consciousness first apprehends in the form of "demonic dread', and which, as it further unfolds, becomes more elevated and ennobled (augustus), is in origin not something rational or moral, but something distinct, non-rational, an object to which the mind responds in a unique way with the special feeling-reflexes that have been described. And this element or "moment" passes in itself though a process of development of its own, quite apart from the other process - which begins at an early stage - by which it is "rationalized" and "moralized", that is, filled with rational ethical meaning. Taking this nonrational process of development first, we have seen how the "daemonic dread', after itself passing through various gradations, rises to the level of "fear of the gods', and thence to "fear of God'....'dread" becomes worship, out of a confusion of inchoate emotions and bewildered palpitations of feeling grows "religio', and out of "shudder" a holy awe (1950:109110).

There is no doubt that Otto is largely right about the analysis provided here of the tendency toward the divine, toward the supernatural, whether in the plural or in the singular, except there is no religion that is absolutely faithful to the singular as we are wont to believe. But this tangential issue is not what we wish to emphasize in this discussion. What we want to note is the fact that Otto and many other scholars of the genesis of religion seem to put the cart before the horse. There is no doubt that humans developed the religious attitude in response to the awe noted here, but the awe itself derives from the fact that we fail to understand why our efforts are rewarded in some instances and in others - similar if not identical - totally and inexplicably thwarted.

Let me be more specific. Most belief systems have ideas about supernatural entities, be they a Supreme Being, deities, divinities, angels, spirits, ancestors, heroes, etc. These entities are postulated to explain all kinds of phenomena, as Otto has acknowledged. But more serious is the use to which we put these entities, in order that our lives may be a little more comfortable. Finding at times that consorting with spirits is helpful, but there may be 
greater forces than accounted for by the spirits which may impel us to want to be in the good books of the greater forces beyond the spirits. Coping mechanisms determine what forces we postulate. And the deference we purvey are also responses to the needs that beset us - either in enhancing life, preventing antagonistic forces from swamping us and destroying us, justifying our claims to certain rights which we wish to deny others, or cementing the bond of social cohesion which makes life tolerable. Whichever way we look at it, we see that it is not simply the mysterium tremendum simplicter that is at work, but we are forced out of necessity to survive and the trial and error of explanatory models that compel us to alight on the idea of these forces. Further we suggest that while we are contemplating the numerous theories of origin of the religious phenomena, such as sociological, psychological, naturalistic, animistic, anthropological, moral, etc. (Amanze, 2002) we should not forget that we have not paid attention to the economic origins of religion, which I consider to be the overriding foundation for religious phenomena.

In traditional societies when humans experience vicissitudes, various explanations are provided. Take, apart from the things we mentioned earlier with regard to the USA, the death of more than 130 in a South Korea subway fire, the rare snowstorm that hit Palestine, statue's "tears" in Bangladesh, over 30 dead in winter rains in Pakistan, India and Afghanistan, the Bali bomb killing hundreds, etc. across the world. These are events for which prayers are being said in churches and mosques across the world, in spite of the fact that we know the cause of most of the problems, and that we have the capacity to stop them or predict them. Recourse to supernaturalistic explanations is not confined to traditional societies, as the same socio-economic concerns of these societies are still very much with contemporary humans. Thinking of the enemy in the form of evil spirits, unsatisfied ancestors, magic, or even offenses against the Supreme Being is not the prerogative of the traditional mind, because, having the forces in our corner, as pugilists about to assault each other doing the sign of the cross before each round shows it is not a matter of not being scientific - it is just being human and recognizing the need to have the support of the forces known and unknown so that success and survival can be guaranteed. It would seem from this that selfinterest is the first law in heaven!

Within Buddhist traditions, as in other traditions which rely on the powers of the unseen to realize salvific gratification for humans, taking refuge serves to elevate the self physically, materially and spiritually. The combination of meditation and good conduct help the society to attain equilibrium and individual quietude. The various festivals that Buddhists observe are related to real life-affirming ideas and must be seen in the light of eliciting the overall interest of humans.

Within Hinduism there is no contradiction in recognition of numerous deities, each individual having a choice of which deity to be attached to, as all the deities are various aspects of the one and only God. This is why, just as in Yoruba religion, it is possible for the father to be devoted to one deity, son to another, mother to a different one and daughter still to a different deity, with there being no conflict or rivalry between the members of the family regarding religious interest which may often be determined by professional affiliation or social demands of office. It is often recognized that the paths may be different but the overall goal they are all seeking is the same - human welfare (Anradha Roma Choudbury, 1994:75). And it is not unimaginable that if you have been attached to a deity for a while and do not see improvements in your lot, you may consider switching to another deity, for you may have been attached to the wrong one out of error, which is what people do even nowadays moving from Islam to Christianity or vice versa, or being related to many relig- 
ions at once, hoping by so doing not to anger any one power, and so be able to harness the benefits that may accrue from such diversification of effort.

In closing this segment one cannot but mention the condescending way in which Amanze (2002) discusses African ideas of the Supreme Being, referring to this Being as the High God, which we may never be able to ascertain whether it is a He or an It or a She, as if it matters (p 21ff). What we need to reaffirm here is the argument of Wiredu (1980) in that classical essay, "How not to compare African traditional thought with Western science", where he argued that the reason why Western scholars fail to see analogies of symbolism and equivalence of doxography is because of poor historical background which clouds their perception, leading to misrepresentations and wrong attributions of ideas to Africans; after all, what could be more analogous than the ideas of spirits, angels, trinity, the Christ, the Patriarchs and the Supreme Being and the divinities, ancestor deities and the Supreme Being in Christianity and African Religions. More importantly to what end were these forces, spirits and entities postulated if not for the overall benefit of human beings in an uncertain world. Would it matter to the forces that we do not recognize them, if we had no need (material, psychological and spiritual) for them?

\section{Origin, Genesis, Source, Ultimate Reality and Terminus ad quiem}

All peoples wish to know where they came from and how they got where they are. This has been the raison d'être for recording the annals of the society and for keeping a record of the genealogical tree. But more important are questions of how humans came into being, how the world came into being and how things came to attain the order they have. But these ideas are not by themselves sacrosanct, for the reason all this information is needed is simply to authenticate claims of ownership that we make to the land we dwell on. The idea of the land between two rivers - Tigris and Euphrates - is no more than a validation mechanism for the land (even though in the case of Jews, as pastoralists, losing control over the land for some time meant separation of ownership when others gained access to it for millennia unchallenged). What better title certificate can humans claim to a land than to say they were the first ones to inhabit the land by virtue of creation starting there and they being the original creatures entrusted with the ownership.

The Yoruba people of South Western Nigeria, Togo and Republic of Benin claim that Ile-Ife was where creation started and expanded to the rest of the world. From this center originates the devolution of powers of rulership over the vast expanse of the Yoruba world, with surrogates of the original descendants of Ile-Ife retaining the power and entitlement to kingship and land ownership, because Oba l'o ni ile. When the Psalmist says: "The earth is the Lord's and the fullness therefore. The world and those who dwell therein" (Psalm 24:1) and the Jews came up with the idea of the "Promised Land" after losing entitlement to that land between the two rivers, clearly the validation of settlement and ownership cannot be more genuine if it was granted by the Supreme Being. Even when as a consequence of occupational decentralization no personal titles are available, the security of ownership cannot be deeper than one vouchsafed by deity.

The obverse of the stories of origins is the stories about ultimate end of the universe and of individual sentient being. For one thing human destiny is always intriguing, either on an individual basis or as corporate matter, thus creating the enigma of cognitive vacuity. Not being there when we were born as conscious beings capable of remembering the events of our birth, it is not strange that we also have to rely on speculation to fathom the origin of "everything", but more curiously that we have to speculate on what happens at the end. 
Because things are hard for sentient beings, and because "fingers are not equal" in this world of scarcity and deprivation of the majority, economic theories of heaven have to be propounded, a space where there will be no want, no scarcity, where everything will be equally available to the rich and to the poor and where each would get according to their desire by merit of a belief. One is not suggesting that all religions have the economic metaphysic but those that do not have postulated other means of arriving at mental and material equilibria.

One would have expected that the warnings of apocalyptic cataclysm would have served to make humans more tolerant of each other and more concerned about the welfare of each other. That is not the case, as the more religious you are the more selfish you seem to become within the two most predatory religions on the continent of Africa. It is not by accident that there is no peace in Nigeria, for example, as a consequence of the divisiveness of religion, which is used as an instrument of control of economic resources of the country, nor in Botswana where Christians believe the only Moral Education worth teaching in the Senior Secondary/High School system is the Christian Ethics! While many African countries may not have the problems of Nigeria, Niger, Cote d'Ivoire, Liberia, Chad, etc., because of the near homogeneity of religion, there is no doubt that the way in which African religions are treated is shameful and regrettable.

We will mention in passing the symbolism of final resting place, and the fact that in many societies the bones of ancestors are exhumed and re-interred on the family land, as a way of cementing the bond between the living, the dead and the land. Where cremations are performed there are still efforts to keep the remains till such a time as they would be properly dispersed symbolically in familiar environments.

\section{Scripture, Text, Codex, Dogma, Doctrine, Disclosure, Revelation, Body of Truth, and Theology}

The need to harness the favours of the powers seen and unseen, for self-interest, leads to the development of various theories about how to get the favours - ideas about what is right and wrong, norms of interaction with these powers and with each other, etc., which lead to texts, doctrines etc. To sanctify this we produce explanations of inspirations, revelations, visions, spirit possessions, apparitions, etc. These help to cement the provenance of the documents so produced. The sacredness of the documents - oral or written - is a certain mark of the insitutionalization of the religions developed, making certain deeds permissible and others taboo. The moment we accept the sacredness of the ideas documented in such texts, we begin to see the need to develop schools of interpretation and format of understanding. The text provides ideas on norms of interpersonal relations, as well as relations to the powers granting the text.

While documents like these may codify the various elements in the religious dogma relating to ideas of origins, nature of deity, the supernatural entities, and the proper ways of relating to these forces, they also help determine the norms of societal, cultural and practical life. In fact, elaborate steps are taken to ensure minimal possibility of strife in society between members and among groups within or without the society, building into the ideas the mechanisms for conflict resolution and restitution where people have been injured materially or spiritually. And in many instances where religion develops custodians of faith, provisions are made for the sustenance of the custodians - so that they can live in ease of mind, without worries about material problems. 


\section{Worship, Rituals, Liturgy, Communion, Meditation,} Prayer and Curses - Raison d'être

In most instances the ideas that people obtain about religion usually come loaded with relational statements between the religious and the object of religion. Even though piety and uprightness are enjoined by the religions, the cloaking of the reasons for such injunctions in metaphysical terminologies deceptively remove the obvious socio-economic foundations of the relationship. Most scholars of religion and religious behaviour are fooled by this metaphysics into concluding that the expressions of submission is reaction to the awesomeness of the great powers before which humans recognize their finitude.

There is no doubt that the enormity of the dimensions of reality is enough to embolden one to a submissive approach to reality; even more understandable is the fact that realization of the limitations of human knowledge is enough to humble the wise, but we cannot gloss over the fact that in every epoch efforts have been made to extend the frontiers of human knowledge, and as a consequence reduce the dependence on the often unpredictable forces beyond human control.

I will not be able to enlist all the materials that will help make our point here. An exhaustive listing is not necessary to the thesis we advance, as each piece of the jigsaw puzzle easily claims its space as we have been articulating the ideas. Consider what we call worship and ask, how much of this worship is devoted to celebrating the greatness of the deity? Even when we celebrate the deity, how much of the praise and adoration is a factor of blackmail so that the deity can continue to be generous toward us? Are the majority of our approaches not derivable from the background of our needs for all sorts of things - material welfare, psychological peace, spiritual warrantee against eternal death, etc.? Does the deity need us the way we need the deity? To what end do we worship, perform ritual, engage in liturgies, make supplications, pray, meditate, etc.?

Examine the factor of prayer: Typical prayer may have elements of thanks and gratitude for previous benefaction for self, for all kinds of imaginable blessings, asking for forgiveness for sins already committed and those yet to be committed, request for all manner of imaginable goodies, from good health to fertility of land and animals and wives and husbands, to guarantee of a space in the "world" to come and closing reminder of the greatness of the deity, without whom all things are meaningless. In a world in which there is acute scarcity it is only reasonable that in praying we also provide justification for why we deserve more of the goodies than our competitors, hence the need to mention what we have done right which our competitors have not done which makes us deserving of assistance. But in asking for assistance we are also asking that the deity not assist our competitor. In many instances we even insist that our competitor does not know this particular deity, hence not deserving of generosity of the deity. Conclusively, rituals, worship, liturgy, communion, prayer and supplications are not as disinterested as we humans wish to make, and we even devise special kinds of prayers for special kinds of needs.

But it will be remiss on my part to finish this section without looking at the other side of prayer, which is curse. Praying for ourselves in a world in which the necessities of life are highly contested means asking for the share of what is available, but we are not always asking for fairness in the sharing of what is available, because our blessing indirectly indicates curse for others - even when we do not go out to curse, we are instinctively doing so. But there are times we go out of our way to invoke curses on our enemies, as the Psalmist does in Psalm 83. This is also what is done when societies make sacrifices, which they hope will expiate some wrong, defraying the punishment and banishing the misgivings of the deity. 
By and large, we are suggesting that the element of prayer, rituals, supplications, sacrifices, communion, etc. are not disinterested acts of glorifying the deities that suffuse the religions, they are indeed ways of assuring the welfare and success of humans. Given the unpredictability of life, the vagaries of existence and the forces of nature, taking the extra insurance mechanism of making sure we are in the good books of the powers that are superior to ours is not something that we take lightly. For example, take someone who has to have surgery for appendicitis, and the family making vows and praying even when they have been assured that it is a minor procedure. What they are doing is taking an insurance policy against the 0.1 percent chance of error on the part of the physician. And as Sodipo (1972) argued, when these matters are at stake, it is those in whose corner the gods are arrayed that the outcome of a dice throw will be favourable ("Notes on the Concept of Cause and Chance in traditional Yoruba thought" in Second Order).

\section{Priesthood, Leadership, Custodians of Faith}

Many reasons can be advanced in support of the existence of a category of persons called leaders in the religions. In the first place, every human being has different talents, and it could be argued that some humans have the talent of relating to the supernatural, and being the ears and the eyes of those of use without such talent. As a consequence it makes sense that we allow those with that talent of relating to the supernatural to do so on our behalf.

Once we make the concession mentioned above, the next step is the issue of division of labour that is implied and the matter of compensation for those who have used their time doing other things to support themselves and their families. Given this situation it makes sense that the society or those who need the services of the religious leaders make contributions to their support.

What we have identified here is that with economic division of labour comes the issue of just reward for just effort. Thus the institutionalization of religion comes at the price of the category of people called Priests or Leaders. What, however, has happened is the fact that the clergy in most religions now have benefits and luxuries which followers do not have, but in so far as the arrangement works for the people involved, no matter how inequitable it may be to outsiders, we cannot complain, because volenti non fit injuria.

\section{Sacred Places, Sites, Spaces, Symbols, Artifacts, Emblems and Art}

In most religions the place where the inspiration derived for the development of the religion is usually regarded as sacred. This indicates the sanctification of originary space, and the development of an attachment which is at once symbolic and at the same time practical. The recognition of sacredness then displays a variety of physical and metaphysical manifestations, all coming to the signification of the use of creativity and entombment of ideas and doctrines.

Nowadays we do find that industries surround the space and symbols of religions, providing big incomes and jobs for millions of persons. This cannot be doubted as we are aware of the art spurned by religions all around us, and millions of dollars that the industry generates on an annual basis.

Speaking of space we cannot but reiterate what we have said about land earlier. But this is not idle repetition, as those aware will know that religious spaces as holy sites are spaces which provide gargantuan revenues for inhabitants of the spaces on a regular basis. Consider the pilgrimages to Mecca and Jerusalem on a yearly basis and imagine how many millions of dollars are generated for the Saudis and which would have been accruing to 
Palestinians and Jews if they could resolve their sibling rivalry gone savage. At the last pilgrimage to Mecca more than two million people came from all parts of the world, with literally nothing but money and clothing with them, having to buy things from the indigenous Saudis. If you assume that each visitor spends just US\$ 500.00 over the two weeks of the journey in Saudi Arabia, multiply that by two million, then you understand why religion has to be a source of strife and why human minds have to be controlled so that those who continue to benefit will not lose the benefit.

In the remaining part of this discussion I will pay attention to religion in Africa, as I believe that the drift of my argument relating to the economic nature of religious need, origin of religions and sustenance of religions has been evident from what we have said thus far. In doing this I will focus only on aspects of the history of the imported religions of Christianity and Islam in Africa.

\section{Religions and the New African Union}

I am not under any illusion that substituting African Union for Organization of African Unity is the solution to Africa's multifarious problems. Nor am I making any claim that religion has been responsible for all of the problems of Africa. In the case of the former, Africans are very good at changing the names of organizations and institutions if only for symbolic window-dressing purposes while making no effort to understand why the organizations they are trying to put aside failed or what could be done to make the new organizations (if only in name) more effective, efficient and useful. It is also clear to me that most Africans are ignorant of the nature of the contemporary international environment in which we have to survive, including African leadership. In fact, most African leaders behave as if they are ignorant of the history of Africa, the denial of African humanity, the destruction of African identity, the pillaging of African material, artistic and human treasures through slavery and colonization, and the subsequent denudation of the African heritage - religious, educational, social, political, scientific, cultural, etc. It is only ignorance that could explain the various disastrous policies of the leadership in Africa that always led to civil wars, pernicious policies and even the looting of treasuries to be banked in Western capitals while the impoverished populations are being taxed to pay dubious debts, which probably never came to the continent in the first place. The part of religion in this insidious heritage of meaninglessness cannot be overstated. I will examine these under the rubric of the questions we raised in our introductory section now.

\section{World Religions - Partners for Progress or Agents of Destruction in Africa?}

The World Religions never concealed their intentions in their initial interface with Africa. The tactics have not changed, nor have the goals been altered. In my judgment the tactics have remained a combination of insult, falsehood, demonization, psychological assault, physical abuse, intellectual negativization and identity destruction. The goals have remained colonization, dispossession, debasement and rehabilitation as a reject, wretched and useless, worthless group with no ideas of right or wrong till the world religions came to put order in the chaos of indigenous space and society.

As a consequence of the above, the first thing that the religions do is to deny the validity, rationality and legitimacy of the traditional and indigenous ways of approaching the Supreme Being by Africans. This is done not only by the clergies of these religions but by the theologians of the world religions. This is done in various ways, subtle and monstrous. This has led to the derogation of the integrity of Africa and Africans, their institutions, their 
identities and their sense of worth. Even now the clergy still refer to the Africans who are not of their faith as pagans, kafirs, or primitives; they never recognize the corpus of ideas that relate to traditional and indigenous religions of Africans. That reminds me, the typology "traditional" is one of the epithets of derogation - as if Islam and Christianity are not the traditional beliefs of the desert peoples of Arabia!

What has happened in the wake of the exclusionary tendencies of the world religions that we are talking about is the fact that they have not only moved away from being humane religions, designed to cater to the lives of humans, to a realm of mystification and mythology, creating accoutrements of doctrinaire fanaticism, thereby creating life and death conflicts wherever they come across each other. This is understandable because these religions developed as contest over the scarce resources of the Arabian desert region, thus wherever they meet, the conflicts of their sibling origins are re-enacted and foisted on the hapless, thoughtless and ignorant converts.

Apart from the ethnic divisions which colonialism has accentuated in Africa, religion has widened the cleavages, which now become open gulfs through which no bridges of understanding and cooperation are possible. There are hardly any African countries in which Christianity and Islam interface where there are not wars, destructive uprisings and debilitating political systems.

Given these developments, to what extent are we justified in expecting anything good to come out of the religions? If in small things religions and their leadership cannot be trusted to act in good faith without fanning the embers of division, are we now to forget our history of the Jihads and the Crusades, the Maitatsenes and the Bin Ladens and expect the leaders to lead us to the Promised Land? Are leaders not more interested in the collection till than in the welfare of their followers, especially in the light of the fact that the religious spaces are the best in the communities where they are located - even when the environing community is full of decadence and squalor, the churches and mosques are elegant and impeccable and the clergies live in opulence?

\section{Do the Religious Leaders teach the Sanctity of all Religions and Equality of all the Paths to the Supreme Being?}

The Pope on his visit to India and the Far East apologized to the Indians about the unfair ways in which the Church treated the faiths of the Indians, dubbing Hinduism primitive, idolatry, barbaric, etc. The Pope has visited Africa so many times, but has never found it fair to apologize to Africans about the ways African religions were treated by his missionaries. One may speculate about reasons for this: Could it be because Africans are black, primitive, intellectually inferior to the Indians and culturally backward? Or could it be that the Indian religious systems are superior to African indigenous religious systems? moreover, neither Islam nor Christianity has apologized for the evils of slavery - whether transSahara or trans-Atlantic - or the colonization of retrogressive ideas about the inferiority of indigenous African cultural, educational, religious, artistic, social, political and intellectual institutions. All kinds of funny names are still reserved for African indigenous institutions and our students now and leaders now ever serve as emissaries of the foreign enslaving and colonizing religions, by saying that Africa has profited from slavery and colonization!

It is not to be expected that a leadership that is not well-versed in the cultures of their ancestors, one that has been totally colonized and debased, one that lacks introspection and inner self-confidence would not recognize the effects of the words that they preach on a daily basis on people, such that, in the end, they fail even to see how what they preach de- 
means and dehumanizes themselves and their audience. If you remove the humanistic aspect of religion, the aspect that works for the welfare of humans, one would wonder what else is left that can benefit a continent reeling from the decimation of slavery, the expropriation of colonization and the pauperization being carried out now by new-colonialism and capitalism in the name of free market and democracy. Would these religious leaders be able to transcend their narrow self-interests and really give the leadership of Africa counsel that is untainted with selfish motives? These are serious considerations which inductive reasoning would suggest circumspection about. But maybe this writer is wrong, maybe the religions have changed and maybe we are now going to witness a new era in human affairs. But where is the optimism to come from when no Christian seems concerned about what the "people of God" are doing to the Palestinians in the "holy land"?

\section{Whose Interest are the Leaders Canvassing with African Leadership?}

I would not be saying much here, because we have said enough about religious leadership already. But one could make bold to say that religious leadership in Africa is neither representative of God nor of the numerous poor souls that throng their fold, given the fact that at every turn religious leaders are seeking prominence and self-perpetuation. Can religion then become the fifth estate of the realm and be expected to perform wonders where the four estates entrusted with directing the affairs of citizens have failed? Well, we may be generous and say, please, do not let us write them off immediately without a hearing or trial. We may even be more sanguine and say that as custodians of faith, whatever they expropriate still remains in the continent in the form of great ritual spots and lives of opulence that rubs off on their followers, instead of being stashed away in European and American banks as African politicians do. Consequently it may be suggested they are still credible by African standards. We will not deny the incurable optimists their rights, because that is what democracy is about, except in America where means of denying the peoples of colour and the poor their franchise have been perfected by brothers in power.

\section{Can Undemocratic Religious Institutions be Instruments for Democratic and Egalitarian Development?}

There are very few traditions of egalitarianism or democracy in religious spaces, as religion intrinsically frowns on insubordination and diffusion of responsibility. Against this background it would be difficult to see how the World Religions will facilitate the quest for equality of human beings when they continue to preach the inequality of persons.

Considered as agents of change, the conservatism of religious institutions are famous, and the allergic nature of religion to revolutions and development cannot be seen as encouragement to lead the masses of the peoples in Africa to the Promised Land where poverty and squalor will be history. Rather, what the religions preach is the turning of the left cheek, fingers are not equal, submission to authority and respect for institutions of power, no matter how unjust, iniquitous and irresponsible such locus of power may be.

In any case would it not be too much to expect intrinsically undemocratic and parasitic leadership now to be the force of liberation of the masses of the poor and dispossessed from their oppressors? It may be said that religion was actually the instrument for the termination of slavery in Africa and the new world. This will be a disingenuous argument, because it is no secret that the imposition of slavery and colonialism was effected with the support, approval and active sponsorship of religion. 


\section{Concluding Remarks}

This essay has taken some twists and turns which have been unavoidable given the enormity of the task set - challenging religion to prove its relevance. Some may be suspicious of the motive for writing the essay, wondering why so much hatred of religion, and why single out Christianity and Islam. Some may even be wondering what religious predilection the writer avows. These will only be tangential points that have little or no relevance to the validity or invalidity of the issues raised here. Before people start praying for my soul, I should hasten to add that I have no hatred for any religion at all, and I recognize that the lives of many would be meaningless without their religions. In fact, what I am calling for is the necessity to redeem the diluted image of the religion.

Why have I not spoken as vehemently against the traditional or indigenous African religions, may be asked. I do not know if the answer that I give will be satisfactory to the advocates of the world religions, but the honest answer that I have for them is this: (a) the indigenous African religions have not caused any wars in any African countries - to the best of my knowledge; (b) the religions of Africa have been traditionally more tolerant than the sibling religions of the Arabian desert which have succeeded in transplanting the disputes over land and resources in the region of their foundation to the African continent at the great peril of African peoples; (c) African religions have always been at the short end of the stick - intellectually derogated, abused, disempowered and dehumanized, to the point that it has never been an official belief system of any state, even though the political leaders visit the leaders of these beliefs in the dark of night to procure support, protection and deliverance; and (d) the fashionable religions that have had so much resources squandered by their leadership should be at least for once responsible enough to face up to the truth and look in the mirror to see the bloody caricatures of whatever ideals they always pretended to have, that they have now become and either shape up or ship out and leave Africa alone.

Thus, all the religions should stop pretending to be either about deity, about human souls, about an apocalypse, about divine truths or such high-sounding notions. They should recognize that religion is about human existence in the here and now, survival of humans in an increasingly competitive world, where humans and humans jostle for meager resources in competition with other sentient beings on earth, and where the leadership of faiths jostle for control over the minds and pockets of their followers to continue to sustain their own dependence on the faith. With these ideas in mind we are able to better begin the investigation of the new research and investigation discipline which I call Economics of Religion, a long overdue discipline in the intellectual arena.

* I thank Drs Joseph Gaie, Oeslie Nthoi, Fidelis Nkomazana, Rev Dr Kealotswe, Ms Elizabeth Motshwapong, Ms Malebogo Kgalemang and other participants at the Conference for their generous, heated and insightful comments on the paper when it was presented. Their comments have helped in further clarifying the ideas expressed in this essay. Though points of contention remain, it is hoped that our explorations have illumined the discourse of the place of religion in society, especially the economic foundations that impel all religious protestations. 


\section{BIBLIOGRAPHY}

Achebe, Chinua 1989. Hopes and Impediments. New York: Double Day, Anchor Books.

Amanze, James N 2002. African Traditional Religions in Malawi-The Case of the Bimbi

Cult. Blantyre, Malawi: Christian Literature Association of Malawi.

Amanze, James N 2002. African Traditional Religions and Culture in Botswana. Gaborone, Botswana: Pula Press.

Appleby, J et al 1994. Telling the Truth about History. New York: Norton \& Co.

Bellan, Robert N et al 1991. The Good Society. New York: Alfred A. Knopf.

Bewaji, JAI 2003. Beauty and Culture. Ibadan, Nigeria: Spectrum Books.

Bewaji, JAI 2000. "Olodumare: God in Yoruba Belief and the Theistic Problem of Evil" in African Studies Quarterly - The online Journal of African Studies.

http://222.Africa.ufl.edu/asq/v2/v2i1a1/bewaji.html

Bewaji, JAI 1992. "A Critical Analysis of the Philosophical Status of Yoruba Ifa Literary Corpus", in Wiener Reihe Vol. VI: pp. 142-155.

Bewaji, JAI 1989. "Human Knowledge and the Existence of God" in Momoh CS et al. (eds.) Nigerian Studies in Religious Tolerance, Vol. IV. Lagos: CBAAC/NARETO. pp. 243-270.

Bewaji, JAI 1985. "African Beliefs" in Oyeneye O and Shoremi M (eds.) Nigerian Life and Culture. Ago-Iwoye, Ogun State Univeristy. pp. 307-360.

Blakey, Thomas D et al (eds.) 1994. Religion in Africa. London: James Currey.

Eastman, Roger (ed.) 1999. The ways of religion. NY: OUP.

Eliade, Mircea 1984. Man and the Sacred. New York: Harper \& Row Publishers.

Fiorenza, ES 1984. Bread Not Stone. Boston: Beacon Press.

Germond, Paul \& de Gruchy, S (eds.) 1997. Aliens in the Household of God. Cape Town: David Philip.

Hallman, David G (ed.) 1994. Ecothology. New York: Orbis Books.

Holm, Jean (ed.) 1994 Worship. London: Pinter

Inglis, F 1993. Cultural Studies. Oxford: Blackwell.

Knitter, Paul F 1986. No Other Name? New York: Orbis Books.

Makinde, M Akin 1988. African Philosophy, Culture and Traditional Medicine. Ohio, Athens: Ohio Universtiy Monographs in International Studies.

Nigosian, SA 1999. World Religions. Boston: Bedford/St. Martins.

Nolan, Albert 1988. God in South Africa. Cape Town: David Philip.

Oduyoye, MA 1995. Daughters of Anowa. New York: Orbis Books.

Otto, Rudolf 1950. The Idea of the Holy. London: OUP

Pagels, Elaine 1989. Adam, Eve and the Serpent. New York: Vintage Books.

Paris, PJ 1995. The Spirituality of African Peoples. Minneapolis: Fortress Press.

Plaskow, Judith 1991. Standing Again at Sinai. San Francisco: Harper.

Ramose, Mogobe B 2002. African Philosophy through Ubuntu. Harare, Zimbabwe: Mond Books.

Rivera, Luis N 1992. A Violent Evangelism. Louisville, Kentucky: John Knox Press. 
Stackhouse, Max L (ed.) 2000. God and Globalization. Harrisburg, Pennsylvania: Trinity Press International.

Smart, Ninian 1992. The World's Religions. Cambridge; Cambridge University Press.

Townes, EM (ed.) 1993. A Troubling in my Soul. New York: Orbis Books. 